\title{
EFFECTS OF THIAZOLE DERIVATIVES ON INTRACELLULAR STRUCTURE AND FUNCTIONS IN MURINE LYMPHOMA CELLS
}

\author{
V. P. HRENIUKH ${ }^{1}$, N. S. FINIUK ${ }^{1,2}$, Ya. R. SHALAI ${ }^{1}$, B. O. MANKO ${ }^{1}$, \\ B. V. MANKO ${ }^{1}$, Yu. V. OSTAPIUK ${ }^{1}$, O. R. KULACHKOVSKYY', \\ M. D. OBUSHAK ${ }^{1}$, R. S. STOIKA ${ }^{1,2}$, A. M. BABSKY $Y^{1 凶}$ \\ ${ }^{1}$ Ivan Franko National University of Lviv, Ukraine; \\ ${ }^{2}$ Institute of Cell Biology, Nationl Academy of Sciences of Ukraine, Lviv; \\ 凶e-mail: andriy.babsky@gmail.com
}

Received: 22 December 2019; Accepted: 27 March 2020

\begin{abstract}
Thiazole derivatives have cytotoxic effects towards tumor cells, such as glioblastoma, melanoma, leukemia and lymphoma. However, the intracellular mechanism of this action is not clear. The aim of our study was to investigate the action of $N$-(5-benzyl-1,3-thiazol-2-yl)-3,5-dimethyl-1-benzofuran-2-carboxamide (BFl) and 7-benzyl-8-methyl-2-propylpyrazolo[4,3-e]thiazolo[3,2-a]pyrimidin-4(2H)-one (PP2) on cellular structure, and bioenergetic functions of mitochondria in Nemeth-Kellner lymphoma cells (NK/Ly). The structure of treated NK/Ly cells and their mitochondria was examined using electron microscopy. The rate of oxygen uptake by isolated mitochondria was recorded by a polarographic method using a Clark electrode. The mitochondrial potential relative values were registered using fuorescence dye rhodamine 123. In the short-term (15 min), incubation with BF1 and PP2 in 10 and $50 \mu M$ concentrations induced apoptotic and necrotic changes in the structure of NK/Ly cells, such as fragmentation and disintegration of the nucleus, destruction of the plasma membrane, and an increase in numbers of lysosomes and mitochondria. A polarographic method did not show significant metabolic shifts in lymphoma mitochondria, in either in vitro or ex vivo actions of the thiazole derivatives. However, fluorescent microscopy showed a significant decrease in mitochondria potential, following a 15 min incubation of cells with $50 \mu M$ of PP2. Thus, the electron and fluorescent microscopy data suggest that mitochondria are involved in the mechanism of cytotoxic action of the studied thiazole derivatives.
\end{abstract}

Key words: lymphoma, mitochondria, membrane potential, thiazole derivatives.

\section{Introduction}

Thiazole derivatives are attractive heterocycles for pharmaceutical and medicinal chemists who design new potent anticancer agents [1-4]. It was shown that two novel thiazole derivatives - N-(5-benzyl-1,3-thiazol-2-yl)-3,5-dimethyl1-benzofuran-2-carboxamide (BF1) and 7-benzyl8-methyl-2-propylpyrazolo[4,3-e]thiazolo[3,2-a] pyrimidin-4(2H)-one (PP2) [5] have a high cytotoxic effect toward various cancer cell lines, such as glioblastoma (U251 and T98G) and human myeloid leukemia (HL 60 and K562) [6, 7]. These compounds also had low toxicity towards human kidney cells
(HEK 293) and human keratinocytes (HaCaT line) $[5,8]$. Previously we have identified that BF1 increased the level of Bax and Bim pro-apoptotic proteins in glioma cells [6], and PP2 increased the level of pro-apoptotic Bim protein and the mitochondriaspecific EndoG nuclease, and decreased the level of the anti-apoptotic $\mathrm{Bcl}-2$ protein in the leukemia cells in vitro [7].

Mitochondria play an important role in cellular metabolism, including production of reactive oxygen species (ROS). It was shown that the studied compounds activate superoxide dismutase and decrease the activity of catalase and glutathione peroxidase

(C) 2020 Hreniukh V. P. et al. This is an open-access article distributed under the terms of the Creative Commons Attribution License, which permits unrestricted use, distribution, and reproduction in any medium, provided the original author and source are credited. 
[9]. These effects may lead to accumulation of $\mathrm{H}_{2} \mathrm{O}_{2}$ in lymphoma cells, which can be toxic for cancer cells. However, changes of other mitochondrial functions, such as respiration, substrate oxidation, oxidative phosphorylation, and membrane potential, during the cytotoxic action remain unclear and need additional study.

Nemeth-Kellner lymphoma (NK/Ly) is used as a tumor model for studying the effect of various antitumor chemical substances. NK/Ly cells are also a convenient tool for the study of tumor cytomorphological changes [10, 11].

The aim of this study was to investigate the action of the novel thiazole derivatives BF1 and PP2 on cellular structure, respiration and membrane potential of mitochondria in NK/Ly lymphoma cells.

\section{Materials and Methods}

Compounds. Thiazole derivatives BF1 and PP2 were synthetized by reaction of 2-amino-5-R-benzyl-1,3-thiazoles with acid chlorides in the presence of triethylamine in dioxane medium at the Chemistry Faculty of Ivan Franko National University of Lviv, Ukraine as previously described [5, 8]. Stock solutions of the tested compounds were prepared in dimethyl sulfoxide (DMSO, Sigma-Aldrich, St. Louis, USA).

NK/Ly lymphoma model. All experiments were conducted on NK/Ly lymphoma cells. NK/Ly cells were obtained from the collection of the Institute of Experimental Pathology, Oncology and Radiobiology NAS of Ukraine (Kyiv). The ascites form of lymphoma was passaged by intraperitoneal inoculation of 10 to $15 \times 10^{6}$ tumor cells to white (outbred) wildtype male mice (22-27 g). Ascites was obtained by drainage of the abdominal cavity with a sterile syringe under ether anesthesia from the $7^{\text {th }}$ to $10^{\text {th }}$ days after inoculation. On the $15^{\text {th }}$ day, NK/Ly cells were withdrawn and injected into other mice to support the lymphoma line in vivo. Later that day, mice were sacrificed using a lethal dose of ether.

Bioethical examination of the experiments on mice was carried out at the Faculty of Biology, Ivan Franko National University of Lviv and was prepared according to protocol No. 11052018 of May 15, 2018.

Preparation and preincubation of NK/Ly cells. Lymphoma cells were obtained from fresh ascites by centrifugation for $5 \mathrm{~min}$ at 1,000 rpm. The pellet was diluted with $0.9 \%$ saline up to the previous volume of ascites (5-8 ml). Suspended cells were incubated on a water bath at $37^{\circ} \mathrm{C}$ with BF1 and PP2 in concentrations of $10 \mu \mathrm{M}$ or $50 \mu \mathrm{M}$ for $15 \mathrm{~min}$. Control cells were incubated for 15 min without compounds. After preincubation, cells were sedimented twice by centrifugation for $5 \mathrm{~min}$ at 1,000 rpm, and washed by saline again.

Isolation of NK/Ly mitochondria. Lymphoma cells were washed by medium A (mM): sucrose (Sigma-Aldrich, USA), 250; ethylene glycol-bis( $\beta$ aminoethyl ether)-N,N, $\mathrm{N}^{\prime}, \mathrm{N}^{\prime}$-tetraacetic acid acid (EGTA, Sigma, USA), 1; 4-(2-hydroxyethyl)-1-piperazineethanesulfonic acid (HEPES, Sigma, USA), $10 ; \mathrm{pH}$ 7.2. Then cells were centrifuged for $5 \mathrm{~min}$ at $1,000 \mathrm{rpm}$. The precipitated cells were resuspended in medium $\mathrm{A}$ to the final volume equal to the volume of ascites and homogenized in a glass-glass homogenizer at $300 \mathrm{rpm}$ for $10 \mathrm{~min}$ at $0^{\circ} \mathrm{C}-2^{\circ} \mathrm{C}$. The homogenate was centrifuged for $10 \mathrm{~min}$ at 3,000 g using a RS 6 centrifuge (Kharkiv, Ukraine) to precipitate nuclei, large cells fragments, and undestroyed cells. The mitochondrial fraction was sedimented by centrifugation of the supernatant for $10 \mathrm{~min}$ at $10,000 \mathrm{~g}$ $\left(0{ }^{\circ} \mathrm{C}-2{ }^{\circ} \mathrm{C}\right)$. Isolated mitochondria were resuspended in medium $\mathrm{A}$ and used for measurement of oxygen consumption.

Measurement of respiration and oxidative phosphorylation in mitochondria. Two types of experiments were performed. In the first type (in vitro), BF1 and PP2 in concentrations of $1 \mu \mathrm{M}, 10 \mu \mathrm{M}$ or $50 \mu \mathrm{M}$ were added directly to the polarographic chamber. In the second type (ex vivo), cells were preincubated with BF1 and PP2, as described above. Control cells were incubated for 15 min without the studied compounds. After preincubation, cells were sedimented twice by centrifugation for $5 \mathrm{~min}$ at 1,000 rpm, and washed by saline solution again. Then mitochondria were isolated as described below.

In the polarographic chamber, mitochondria were incubated in medium B (containing (mM): sucrose, 250; HEPES (Sigma, USA), 10; EGTA (Sigma, USA), 1; KH2PO4 (Sigma, USA), 1; $\mathrm{MgCl}_{2}$ (SigmaAldrich, USA), $1 ; \mathrm{pH} 7.2))$. $\alpha$-ketoglutarate (1 mM, Sigma-Aldrich, USA) and succinate $(0.35 \mathrm{mM}$, Sigma-Aldrich, USA) were used as exogenous oxidative substrates. The rates of oxygen consumption in various metabolic states and the efficiency of ATP synthesis were estimated with polarographic technique using a Clark electrode. A representative trace of oxygen consumption is presented in Fig. 1. The rates of respiration of mitochondria were measured in three metabolic states described by Chance and 


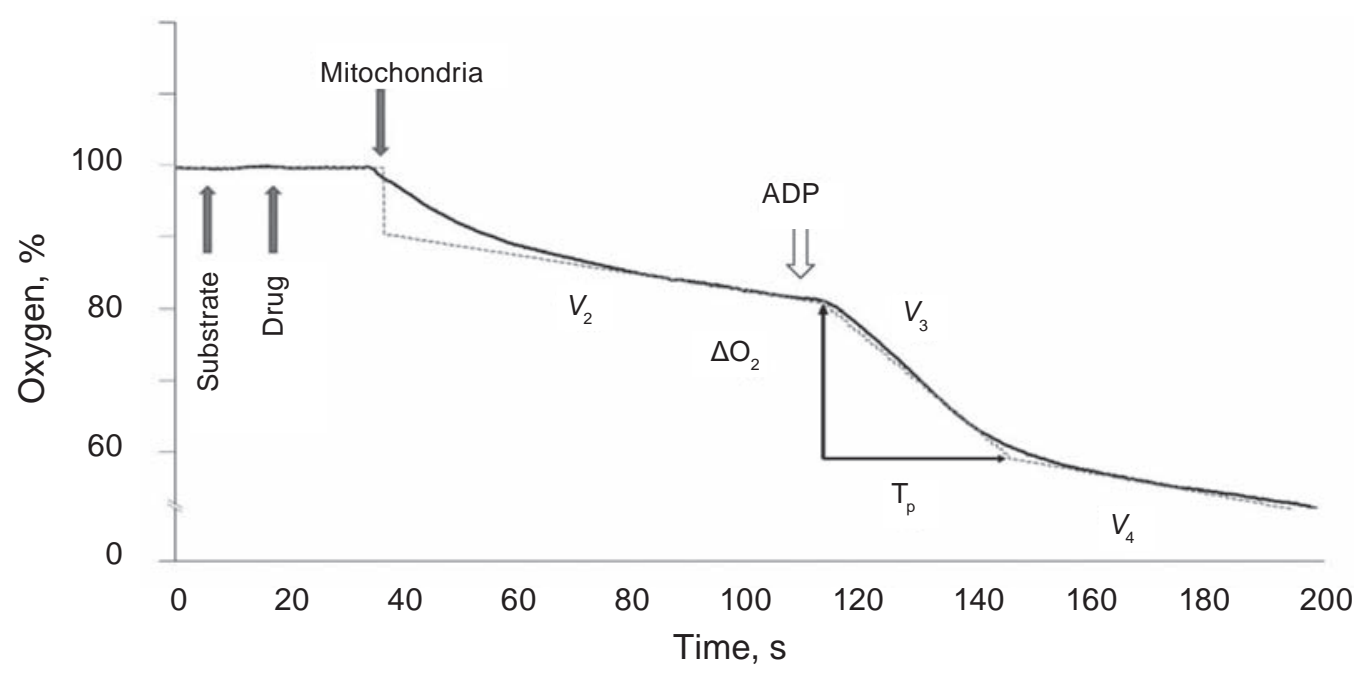

Fig. 1. Representative graphical trace of oxygen uptake by isolated mitochondria of NK/Ly lymphoma cells. Solid line shows primary trace and dotted line represent linearized and calculated data. V2, V3 and V4 represent respiratory rates in metabolic states 2, 3 and 4, respectively [14]. In "active" state 3, $50 \mu M$ ADP was added. Tp - time of ADP phosphorylation. ADP - adenosine diphosphate

Williams $[12,13]$. In “active” state 3 , when mitochondrial respiration is accompanied with ATP synthesis, $50 \mu \mathrm{M}$ ADP was added. Respiration rate was normalized by protein quantity, and measured by the Lowry method [14].

Measurement of mitochondrial potential. To estimate the mitochondrial potential, staining of the $\mathrm{NK} /$ Ly cells with the green-fluorescent dye rhodamine 123 was performed using a modified protocol as previously described [15]. Briefly, cells were incubated with rhodamine $123(0.2 \mu \mathrm{M})$ for $15 \mathrm{~min}$ in medium A. An Olympus IX73 inverted microscope (Olympus Corp., Tokyo, Japan) with a DP-74 digital camera was used to study the membrane potential of mitochondria. Relative mitochondrial potential values were registered using the following fluorescent parameters: excitation filter $470-490 \mathrm{~nm}$, beam splitter $500 \mathrm{~nm}$, and barrier filter $515 \mathrm{~nm}$. A drop of the mixture of cells and rhodamine 123 was applied to a glass slide and placed under the microscope with magnification $\times 12.6$. Five different fields of view of each slide in the visible and fluorescent light spectrum were randomly selected for analysis.

Electron microscopy of NK/Ly cells. NK/Ly lymphoma cells were incubated on a water bath at $37^{\circ} \mathrm{C}$ with BF1 and PP2 at $10 \mu \mathrm{M}$ or $50 \mu \mathrm{M}$ concentrations for $15 \mathrm{~min}$. Then cells were washed by cacodylate buffer and fixed with a solution of glutaraldehyde and OsO4 and then by uranyl acetate. Samples were washed and dehydrated by ethanol, transferred to an epoxidic resin and placed in capsules for polymerization. Slices were made using ultramicrotome UMTP-6M (Selmi, Sumy, Ukraine), contrasted, and photographed in the transmission electron microscope PEM-100 (Electron-SELMI, Ukraine) [16].

Data analysis. Polarographical data were analyzed with MitoDancer software [12]. Fluorescent microscopy data were analyzed with CellStitcher software. Both softwares were created by the authors. The significance of differences between experimental groups was calculated using Student $t$ test and MS Excel 2010 software (Microsoft Corp., Redmond, WA, USA). Statistical differences with $P \leq 0.05$ were considered to be significant.

\section{Results}

Morphological changes of lymphoma cells under the action of thiazole derivatives. Qualitative analysis of the electron microscopy images of NK/ Ly lymphoma control cells revealed the presence of major cell organelles, such as nucleus (1), nucleolus (2), mitochondria (3), and lysosomes (4) (Fig. 2, A). The nuclei have preferably an oval shape and contain one or more well formed nucleoli. The nuclei occupy a large part of the cells (38.1\% of the square). In control lymphoma cells the ratio of nucleus/cytoplasm (N/C ratio) was 0.69. Mitochondria of various sizes and shapes are clearly visible due to the high electronical density of the mitochondrial matrix, while 

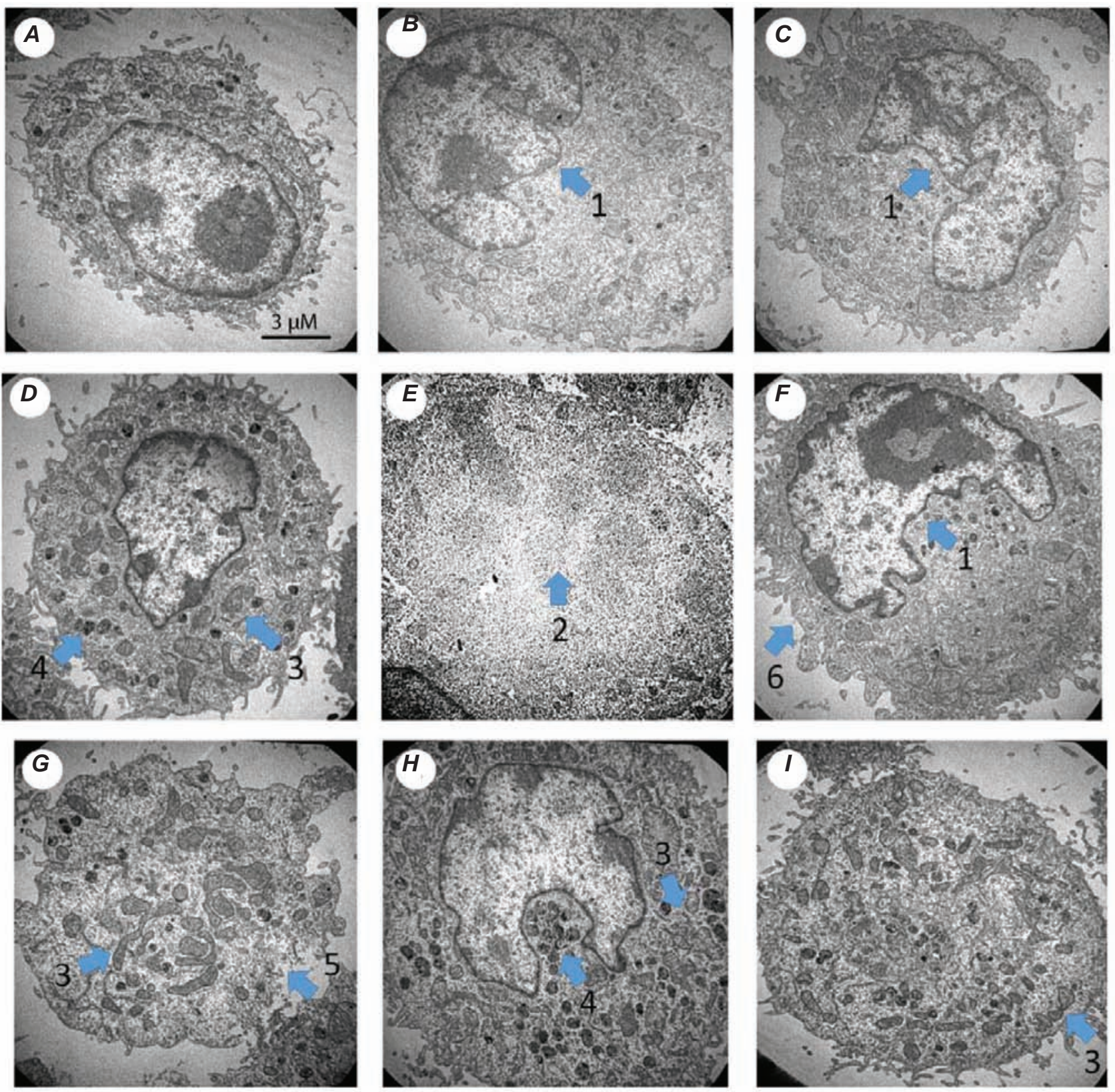

Fig. 2. Effect of thiazole derivatives on the structure of NK/Ly lymphoma cells. (A) control cell, (B), (C) cells treated with $10 \mu M B F 1,(\mathbf{D}),(\boldsymbol{E})$ cells treated with $50 \mu M B F 1,(\boldsymbol{F}),(\boldsymbol{G})$ cells treated with $10 \mu M P P 2,(\boldsymbol{H}),(\mathbf{I})$ cells treated with $50 \mu M$ PP2. Blue arrows indicate: 1 -deformation of nucleus; 2 -digestion; 3 - mitochondria; 4 -lysosomes; 5 -disintegration of plasma membrane; 6 -blebbing

mitochondrial cristae look slightly brighter. The numbers of mitochondria per cell slice are considerably different and varied from 3 to 33 with a mean of 17.3 organelles per cell slice $(n=18)$. Some number of lysosomes ( $\sim 11$ per cell) were identified in control cells as well.

BF1 (Fig. 2, $B$ and $C$ ) and PP2 (Fig. 2, $F$ and $G)$ at $10 \mu \mathrm{M}$ caused apoptotic destructive changes in lymphoma cells. In particular, the cells shrank and lost their elliptical shape. The nuclei were deformed and decreased $(B, C$, and $F)$, while some cells lost their nucleus $(G)$. Chromatin was distributed sporadically ( $D$ and $F$ ). The plasma membrane was changed in some cells due to their blebbing $(F)$. The number and shape of mitochondria differ considerably in comparison to control. The number of mitochondria per cell varied from 8 to 35 with a mean of 19.9 (BF1) and 22.4 (PP2) organelles per 
cell. Some mitochondria contain parallel cristae ( $B$ and $C$ ), while others had swollen cristae $(F)$. The number of lysosomes slightly increased up to a mean of 18.1 (BF1) and 16.8 (PP2) per cell in comparison to control.

BF1 (Fig. 2, $D$ and $E$ ) and PP2 (Fig. 2, $H$ and $I$ ) at $50 \mu \mathrm{M}$ caused even more destructive changes in the lymphoma cells through mostly necrosis (Fig. 2, $C)$. Almost all of the treated cells were swollen in comparison to control (A). Many cells had structural destructions, such as deformation ( $D$ and $H$ ) or even loss of the nucleus ( $E$ and $I$ ), sporadic distribution of chromatin in the nucleus ( $D$ and $H$ ), damage of the plasma membrane $(H)$, and an increase in number and area of lysosomes $(D$ and $H)$. The number of mitochondria per cell varied from 9 to 40 with a mean of 22.1 (BF1) and 24.7 (PP2, **P $<0.01$ vs control) organelles per cell. The shape of mitochondria differed considerably and included the giant size organelles $(H)$. Some nucleus-free cells contained a huge number of mitochondria (Fig. 2, $G$ and $I$ ). The intracellular organelles in some cells were completely digested $(E)$.

Respiration of NK/Ly mitochondria under the in vitro and ex vivo actions of thiazole derivatives. The respiratory rates of mitochondria in metabolic state 3 with both $\alpha$-ketoglutarate or succinate as substrate were not significantly changed when thiazole derivatives at $1 \mu \mathrm{M}, 10 \mu \mathrm{M}$ and $50 \mu \mathrm{M}$ were added directly to mitochondria in the polarography chamber (Fig. 3). All other parameters, such as respiration rates in the second and fourth states, respiratory controls, ADP/O ratio, time and rate of phosphorylation remain mostly unchanged (data not shown).

In a suspension of isolated mitochondria, some intracellular signaling pathways are not revealed. Thus, in the next set of ex vivo experiments, we incubated NK/Ly lymphoma cells with BF1 and PP2 at $10 \mu \mathrm{M}$ and $50 \mu \mathrm{M}$ for $15 \mathrm{~min}$, followed by isolation of mitochondria. However, the respiratory rate (state 3) of mitochondria, isolated from cells pretreated with BF1 and PP2, was also not changed significantly (Fig. 4). Similar to the in vitro experiments presented above, all other polarographic parameters (respiration rates in second and fourth states, respiratory controls, ADP/O, both time and rate of phosphorylation) were also mostly unchanged (data not shown).

Effect of thiazole derivatives on mitochondrial potential. In order to further investigate the role of mitochondria under the effects of BF1 and PP2 we measured the membrane potential of lymphoma cell mitochondria. Membrane potential is an important indicator of mitochondrial activity, which can be detected in particular, by fluorescence microscopy using rhodamine 123 dye [15]. Carbonyl cyanide $\mathrm{p}$ trifluoromethoxyphenylhydrazone (FCCP) - an uncoupler of ATP synthesis - was used to confirm the mitochondrial functional activity and that depolarization of mitochondria was associated with rhodamine 123 fluorescence. Since the test compounds were dissolved in the DMSO, the effect of this solvent on the membrane potential of mitochondria was also tested. It was found that FCCP reduced the fluorescence intensity by $36 \%(P<0.001)$, indirectly confirming the functional activity of NK/Ly lymphoma cell mitochondria (Fig. 5). At the same time, DMSO did not significantly change the membrane potential of mitochondria. PP2 at the concentration of $50 \mu \mathrm{M}$, but not at $10 \mu \mathrm{M}$, significantly decreased mitochondrial membrane potential of NK/Ly cells by $39.5 \%(P<0.05)$. BF1 $(10$ and $50 \mu \mathrm{M})$ did not change the membrane potential. It is interesting to note that in cells with $50 \mu \mathrm{M}$ of PP2, a distinct blebbing of the plasma membrane was observed, indicating apoptosis development.

\section{Discussion}

In our previous studies, we found that the novel thiazole derivatives BF1 and PP2 activate caspasedependent and mitochondria-associated mechanism of apoptosis [6, 7]. In order to reveal potential morphological changes in mitochondria in NK/Ly lymphoma cells under treatment with BF1 and PP2, we have carried out the electron microscopy study of these cells. The obtained images demonstrated both the apoptotic and necrotic changes caused by the thiazole derivatives, such as deformation and disintegration of the nucleus, blebbing and destruction of the plasma membrane, and significant increases in the area and number of lysosomes. Such changes may lead to the endocytosis and phagocytosis of the lymphoma cells by lysosomes and the immune system, respectively. We hypothesized that an increase in the number of mitochondria caused by PP2 might be a way to compensate for damages of the mitochondrial membrane that lead to a decrease in the ATP production. However, to confirm this hypothesis, further experimental testing is needed.

To address the mechanisms of action of BF1 and PP2 on the respiration and membrane potential of mitochondria in NK/Ly lymphoma cells, we have 

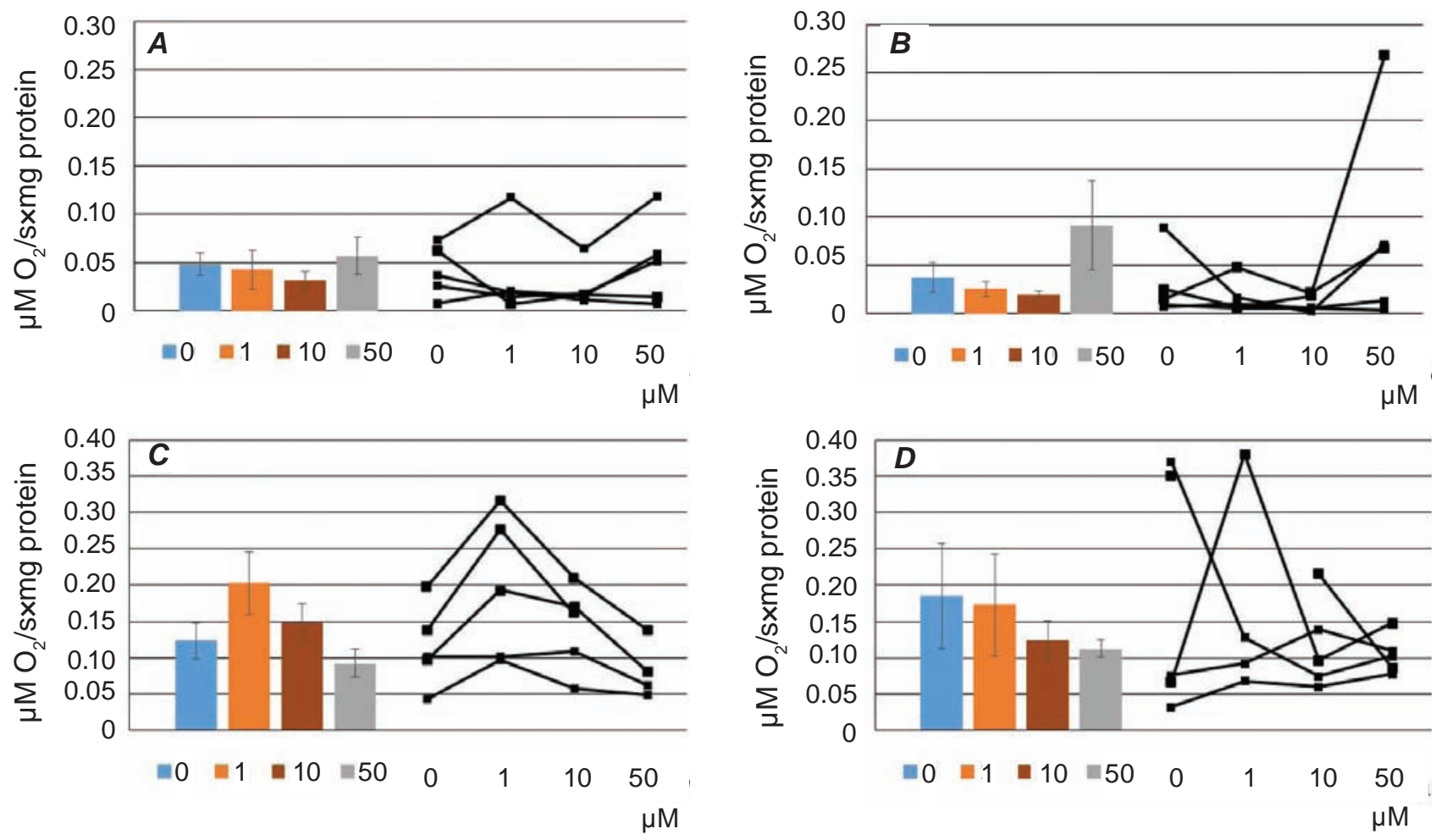

Fig. 3. Respiration rates of the NK/Ly lymphoma cell mitochondria treated in vitro for 15 min with BF1 (A) and (B) and PP2 (C) and (D). Concentrations of BF1 and PP2 (in $\mu M$ ): 0 (control), 1, 10 and 50. Substrates: succinate $(0.35 \mathrm{mM},(\mathbf{A})$ and $(\boldsymbol{C}))$ and $\alpha$-ketoglutarate $(1 \mathrm{mM},(\mathbf{B})$ and (D)). Respiration rates in metabolic state $3\left(V_{3}\right)$ are presented on the $Y$-axis. The color bars represent the mean values of $V_{3}$ with standard error of the mean, while the black line graphs show absolute values of $V_{3}(n=4-5)$. BF1 - N (5-benzyl-1,3thiazol-2-yl)-3,5-dimethyl-1-benzofuran-2-carboxamide; PP2 - 7-benzyl-8-methyl-2-propylpyrazolo[4,3-e] thiazolo[3,2-a]pyrimidin-4(2H)-one

measured these parameters of the mitochondria in vitro and ex vivo. We assumed that BF1 and PP2 decrease the rate of respiration, however, we did not find significant changes in the state 3 of mitochondria respiration neither in vitro, nor ex vivo. There were also no changes under BF1 and PP2 action in the respiration rates in second and fourth states, respiratory controls, ADP/O, both time and rate of phosphorylation in the mitochondria isolated from the NK/Ly cells.

We speculate that the absence of significant effects in in vitro and ex vivo might be explained by the multidirectional and synergic effects of the studied thiazole derivatives: 1) increase in the number of mitochondria; 2) release of cytochrome c from mitochondria [17]; 3) apoptotic and necrotic changes in NK/Ly lymphoma cells; and 4) heterogenic state of lymphoma cells in suspension and of their mitochondria [12]. In addition, the experimental conditions of the polarographic study need using a broader range of the oxidative substrates (e.g., glutamate and pyruvate). One can speculate that a 15 min incubation of cells with thiazole derivatives is too short. However, the results of the electron microscopy study demonstrated drastic changes in the number and shape of mitochondria at this incubation term. These changes in the ultrastructure of mitochondria together with a decrease in the membrane potential of mitochondria suggest their role in the mechanism of action of the thiazole derivatives under study.

\section{Conclusion}

In the short-term (15 min), incubation of thiazole derivatives $\mathrm{BF} 1$ and $\mathrm{PP} 2$ at concentrations of 10 and $50 \mu \mathrm{M}$ induced apoptotic and necrotic changes in the structure of NK/Ly lymphoma cells, such as fragmentation and disintegration of the nucleus, destruction of the plasma membrane, and an increase in the numbers of lysosomes and mitochondria. The thiazole derivative effects in mitochondria were not 

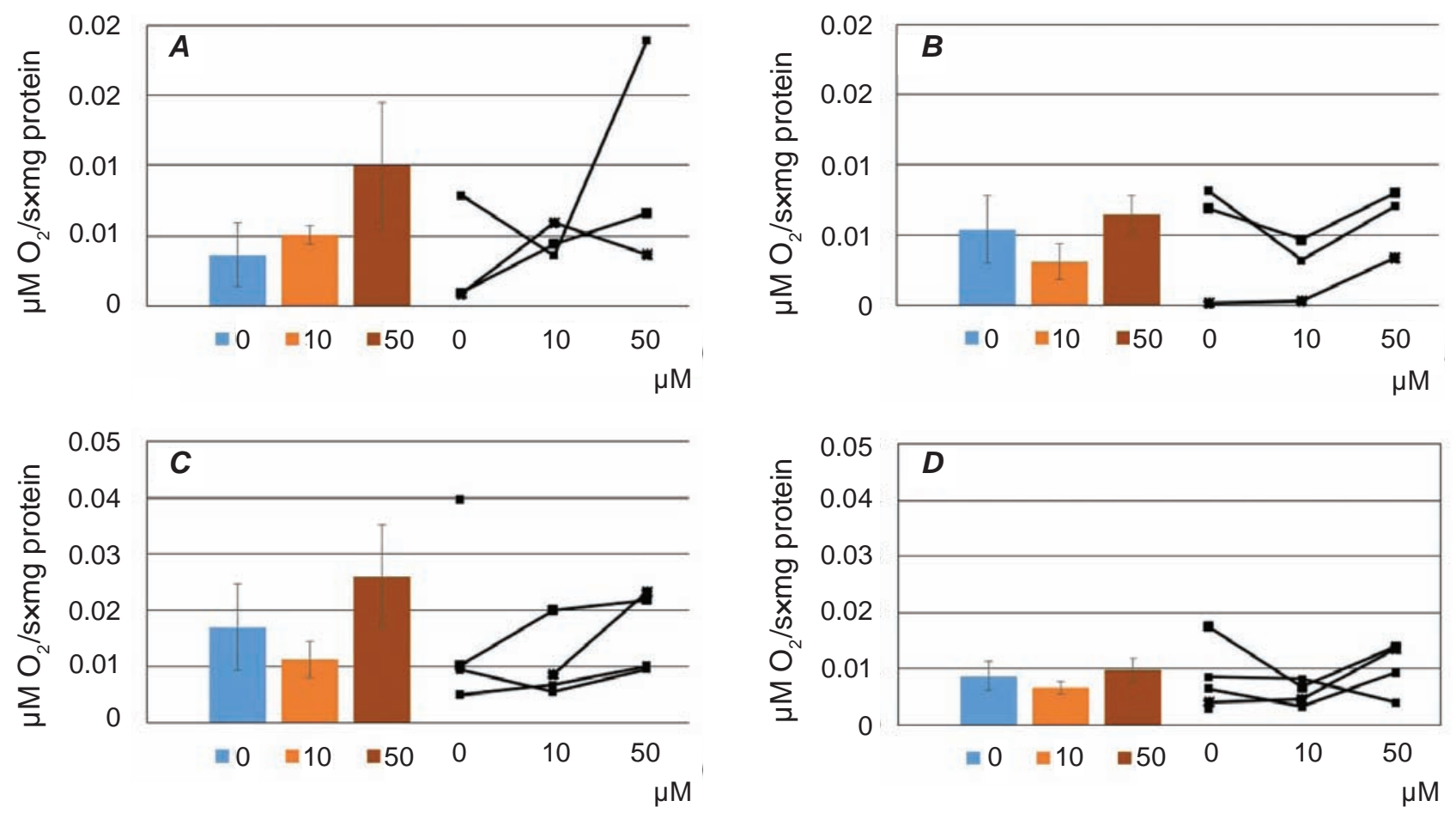

Fig. 4. Respiration rates of the NK/Ly lymphoma cell mitochondria treated ex vivo for 15 min with BFI (A) and (B) and PP2 (C) and (D). Concentrations of BF1 and PP2 (in $\mu M$ ): 0 (control), 10 and 50. Substrates: succinate $(0.35 \mathrm{mM},(\mathbf{A})$ and $(\boldsymbol{C}))$ and $\alpha-k e t o g l u t a r a t e(1 \mathrm{mM},(\boldsymbol{B})$ and $(\mathbf{D}))$. Respiration rates in metabolic state $3\left(V_{3}\right)$ are presented on the $Y$-axis. The color bars represent the mean values of $V_{3}$ with standard error of the mean, while the black line graphs show absolute values of $V_{3}(n=4-5)$. BF1 - N (5-benzyl-1,3-thiazol-2-yl)-3,5-dimethyl1-benzofuran-2-carboxamide; PP2 - 7-benzyl-8-methyl-2-propylpyrazolo[4,3-e]thiazolo[3,2-a]pyrimidin4(2H)-one

detected, when a polarographic method was used. However, fluorescent microscopy showed a significant decrease in mitochondrial potential, following a 15 min incubation of cells with $50 \mu \mathrm{M}$ of PP2. Thus, electron and fluorescent microscopy data suggest that the mitochondria are involved in the mechanism of cytotoxic action of the studied thiazole derivatives.

Conflict of interest. Authors have completed the Unified Conflicts of Interest form at http://ukrbiochemjournal.org/wp-content/uploads/2018/12/ coi_disclosure.pdf and declare no conflict of interest.
Acknowledgment and Funding sources. This research was supported by the Ministry of Education and Science of Ukraine grants (registration numbers 0116U001533 and 0119U000221), Cedars-Sinai Medical Center's International Research and Innovation in Medicine Program and the Association for Regional Cooperation in the Fields of Health, Science and Technology (RECOOP HST) Association and the participating Cedars-Sinai Medical Center - RECOOP Research Centers (CRRCs). 

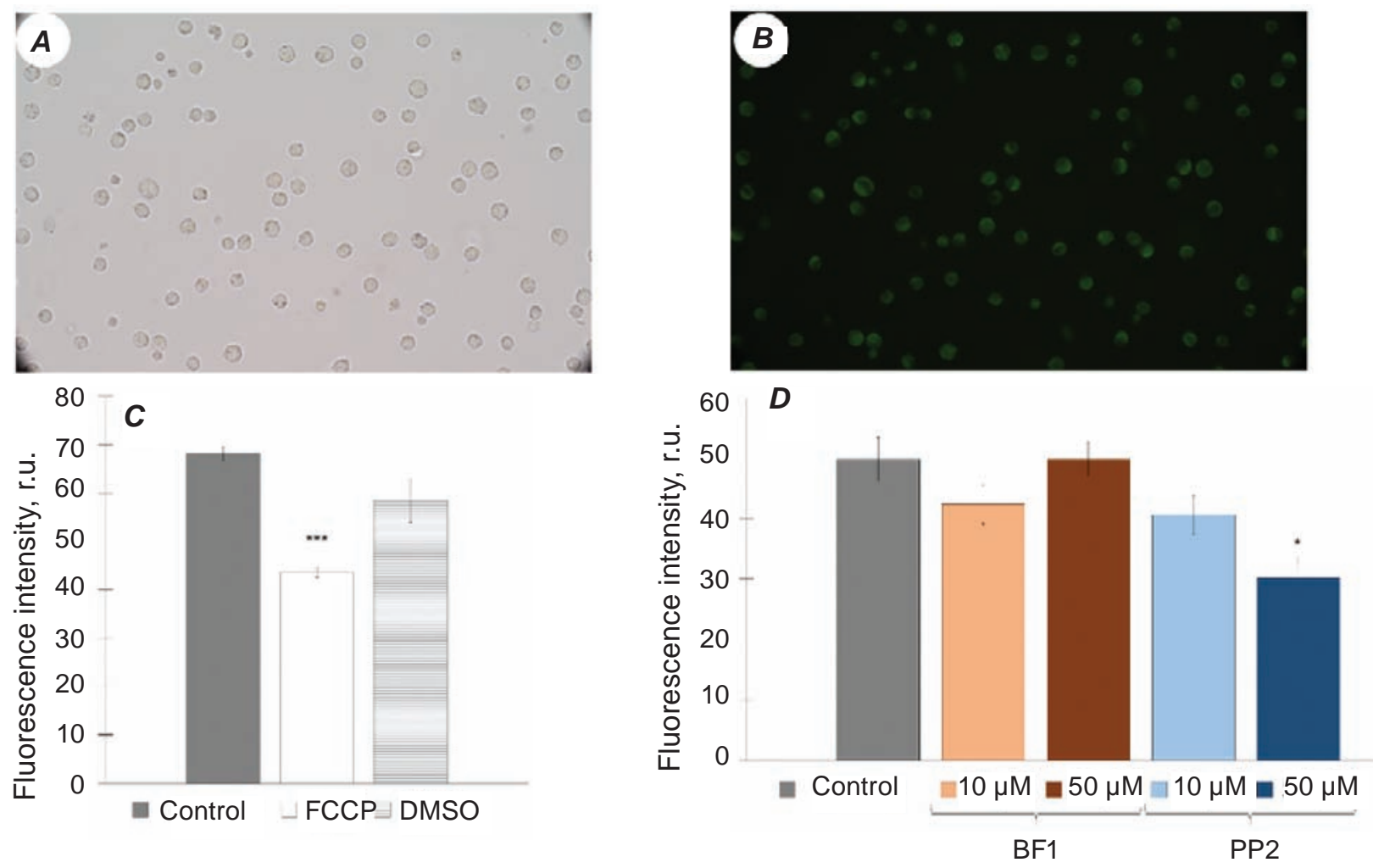

Fig. 5. Fluorescence microscopy and changes of membrane potential of NK/Ly lymphoma cells. Cells were pre-incubated $15 \mathrm{~min}$ with BF1 (10 and $50 \mu \mathrm{M})$ or PP2 (10 and $50 \mu \mathrm{M})$. The mitochondrial potential relative values were registered using fluorescent dye rhodamine 123. $M \pm m ; n=6$. ${ }^{*} P<0.05 ; * * * P<0.001$. (A) light microscopy of NK/Ly lymphoma cells, (B) fluorescent microscopy of NK/Ly lymphoma cells stained with rhodamine 123, (C) effect of FCCP and DMSO on membrane potential of mitochondria of NK/Ly cells ex vivo, (D) effect of BF1 and PP2 on membrane potential of mitochondria of NK/Ly cells ex vivo. BF1-N (5-benzyl-1,3thiazol-2-yl)-3,5-dimethyl-1-benzofuran-2-carboxamide; DMSO - dimethyl sulfoxide; FCCP - carbonyl cyanide p-trifluoromethoxyphenylhydrazone; PP2 - 7-benzyl-8-methyl-2-propylpyrazolo[4,3-e]thiazolo[3,2-a] pyrimidin-4(2H)-one

\section{ВПЛИВ ПОХІДНИХ ТІАЗОЛУ НА ВНУТРІШНЬОКЛІТИННУ СТРУКТУРУ ТА ФУНКЦІї КЛІТИН МИШАЧОЇ ЛІМФОМИ}

\section{В. П. Гренюх ${ }^{1}$, Н. С. Фінюк ${ }^{1,2}$, \\ Я. Р. Шалай' Б. О. Манько Ю. В. Остап'юк', О. Р. Кулачковський ${ }^{1}$, М. Д. Обушак ${ }^{1}$, Р. С. Стойка, А. М. Бабський}

${ }^{1}$ Львівський національний університет імені Івана Франка, Україна;

${ }^{2}$ Інститут біології клітини НАН України, Львів; e-mail: andriy.babsky@gmail.com

Новосинтезовані похідні $є$ цитотоксичними щодо пухлинних клітин гліобластоми, меланоми, лейкемії та лімфоми. Однак внутрішньоклітинний механізм цієї дії ще нез'ясований. Метою даної роботи було дослідити дію N-(5-бензил-1,3-тіазол-2-іл)-3,5диметил-1-бензофуран-2-карбоксаміду (БФ1) та 7-бензил- 8-метил-2-пропілпіразоло [4,3-е] тіазоло [3,2-а] піримідин-4 (2Н)-ону (ПП2) на клітинну структуру та біоенергетичні параметри мітохондрій у клітинах мишачої лімфоми NK/ Ly. Структуру клітин NK/Ly досліджували за допомогою електронної мікроскопії. Швидкість поглинання кисню ізольованими мітохондріями реєстрували полярографічним методом, використовуючи електрод Кларка. Відносні значення потенціалу мітохондрій реєстрували за допомогою флуоресцентного барвника Родаміну 123. За інкубації (15 хв) БФ1 і ПП2 у концентраціях 10 i 50 мкМ спричиняли апоптичні та некротичні 
зміни у клітинах NK/Ly, зокрема фрагментацію та дезінтеграцію ядра, руйнування плазматичної мембрани, збільшення кількості лізосом i мітохондрій. За дії похідних тіазолу in vitro та ex vivo мітохондрії клітин лімфоми не зазнавали статистично значимих метаболічних змін під час використання полярографічного методу. Однак, метод флуоресцентної мікроскопії показав достовірне зниження потенціалу мітохондрій після 15 хвилин інкубації клітин із 50 мкМ ПП2. Таким чином, дані електронної та флуоресцентної мікроскопії дають змогу дійти висновку, що мітохондрії залучені до механізму цитотоксичної дії досліджуваних похідних тіазолу.

К л ю ч о в і с л о в а: лімфома, мітохондрії, мембранний потенціал, похідні тіазолу.

\section{References}

1. Rahmouni A, Souiei S, Belkacem MA, Romdhane A, Bouajila J, Ben Jannet $\mathrm{H}$. Synthesis and biological evaluation of novel pyrazolopyrimidines derivatives as anticancer and anti-5-lipoxygenase agents. Bioorg Chem. 2016; 66: 160-168.

2. Kurumurthy C, Veeraswamy B, Sambasiva Rao P, Santhosh Kumar G, Shanthan Rao P, Loka Reddy V, Venkateswara Rao J, Narsaiah B. Synthesis of novel 1,2,3-triazole tagged pyrazolo[3,4-b]pyridine derivatives and their cytotoxic activity. Bioorg Med Chem Lett. 2014; 24(3): 746-749.

3. Kandeel MM, Refaat HM, Kassab AE, Shahin IG, Abdelghany TM. Synthesis, anticancer activity and effects on cell cycle profile and apoptosis of novel thieno[2,3-d]pyrimidine and thieno[3,2-e] triazolo[4,3-c]pyrimidine derivatives. Eur J Med Chem. 2015; 90: 620-632.

4. Nagender P, Naresh Kumar R, Malla Reddy G, Krishna Swaroop D, Poornachandra Y, Ganesh Kumar C, Narsaiah B. Synthesis of novel hydrazone and azole functionalized pyrazolo[3,4-b]pyridine derivatives as promising anticancer agents. Bioorg Med Chem Lett. 2016; 26(18): 4427-4432.

5. Finiuk NS, Hreniuh VP, Ostapiuk YuV, Matiychuk VS, Frolov DA, Obushak MD, Stoika RS, Babsky AM. Antineoplastic activity of novel thiazole derivatives. Biopolym Cell. 2017; 33(2): 135-146.
6. Finiuk N, Klyuchivska O, Ivasechko I, Hreniukh V, Ostapiuk Yu, Shalai Ya, Panchuk R, Matiychuk V, Obushak M, Stoika R, Babsky A. Proapoptotic effects of novel thiazole derivative on human glioma cells. Anticancer Drugs. 2019; 30(1): 27-37.

7. Finiuk NS, Ivasechko II, Klyuchivska O Yu, Ostapiuk YuV, Hreniukh VP, Shalai YaR, MatiychukVS, Obushak MD, Babsky AM, Stoika RS. Apoptosis induction in human leukemia cells by novel 2-amino-5-benzylthiazole derivatives. Ukr Biochem J. 2019; 91(2): 29-39.

8. Finiuk NS, Ostapiuk YuV, Hreniukh VP, Shalai YaR, Matiychuk VS, Obushak MD, Stoika RS, Babsky AM. Evaluation of antiproliferative activity of pyrazolothiazolopyrimidine derivatives. Ukr Biochem J. 2018; 90(2): 25-32.

9. Shalai YaR, Popovych MV, Kulachkovskyy OR, Hreniukh VP, Mandzynets SM, Finiuk NS, Babsky AM. Effect of novel 2-amino5-benzylthiazole derivative on cellular ultrastructure and activity of antioxidant system in lymphoma cells. Stud Biol. 2019; 13(1): 51-60.

10. Lootsik MD, Lutsyk MM, Stoika RS. NemethKellner lymphoma is a valid experimental model in testing chemical agents for antilymphoproliferative activity. OJBD. 2013; 3(3A): $1-6$.

11. Panchuk RR, Boiko NM, Lootsik MD, Stoika RS. Changes in signaling pathways of cell proliferation and apoptosis during NK/ Ly lymphoma aging. Cell Biol Int. 2008; 32(9): 1057-1063.

12. Hreniukh V, Lootsik M, Kulachkovsky O, Stoika R, Babsky A. Comparative characteristics of respiration and oxidative phosphorylation in mitochondria of cells of mouse liver and lymphoma NK/Ly. Stud Biol. 2015; 9(2): 39-50.

13. Chance B, Williams GR. Respiratory enzymes in oxidative phosphorylation. III. The steady state. J Biol Chem. 1955; 217(1): 409-427.

14. Lowry $\mathrm{OH}$, Rosebroughh NJ, Farr AL, Randall RJ. Protein measurement with the Folin phenol reagent. J Biol Chem. 1951; 193(1): 265275.

15. Manko BO, Bilonoha OO, Manko VV. Adaptive respiratory response of rat pancreatic acinar cells to mitochondrial membrane depolarization. $U \mathrm{kr}$ Biochem J. 2019; 91(3): 34-45. 
16. Hreniukh V, Bychkova S, Kulachkovsky O, Babsky A. Effect of bafilomycin and NAADP on membrane-associated ATPases and respiration of isolated mitochondria of the murine NemethKellner lymphoma. Cell Biochem Funct. 2016; 34(8): 579-587.
17. Filchenkov OO, Stoika RS. Apoptosis and cancer: from theory to practice. Ternoril: TDMU: Ukrmedknyha, 2006. 524 p. (In Ukraininan). 